\title{
New guidelines for health care for alcohol and drug users and the real work: possible contributions of ergonomics to the restructuring of work and competence development
}

\author{
Daniela Tonizza de Almeida ${ }^{\mathrm{a},{ }^{*}}$ e Eliza Helena de Oliveira Echternacht $\mathrm{t}^{\mathrm{b}}$ \\ ${ }^{\mathrm{b}}$ Department of Production Engineering, Engineering School, Federal University of Minas Gerais, Av Antônio \\ Carlos 6627- PCA, sala 3300, Pampulha, Belo Horizonte, MG - Brazil \\ ${ }^{\mathrm{b}}$ Department of Production Engineering, Engineering School, Federal University of Minas Gerais, Av Antônio \\ Carlos 6627- PCA, sala 3300, Pampulha, Belo Horizonte, MG - Brazil
}

\begin{abstract}
The study investigated, through a literature review, how the research community has addressed the difficulties experiences by the teams in front of new prescriptions for the treatment of alcohol and drug users in Centers of Psyco-social Attention and discusses the relevance of the conceptual and methodological references of Ergonomics for understand and transform work situations. Such studies tend to do an analysis that does not account for variability present in both the workers and work organization and prioritize the analysis of final results of the, disqualifying local inventions due to tasks imposed by policy guidelines. It is estimated that the Ergonomics, considering the diversity of training, learning and experience, contributes to the implementation of media to promote the continued development of competences that can meet the demands of production and expands knowledge about the problems experienced and the possibilities of overcoming them.
\end{abstract}

Keywords: Tecnological innovation, Variability, Competences.

\section{Introduction}

In the last ten years, the Psychiatric Reform and the National Policy for Health Care User of alcohol and drugs [1] proposed new guidelines for working, including:

- Shift the asylum and psychiatric apparatus for the creation of new assistance services articulated the logic of territory where the Centers of Psyco-social Attention (CAPS), especially al- cohol and drug mode (CAPS ad), play a central role;

- Changes in work design and work products, focusing on psychosocial rehabilitation and harm reduction in a perspective of integral and individualized care;

- Changes in work organization through horizontal and participatory practices involving personal manager, interdisciplinary teams of professionals, users, families and communities.

\footnotetext{
*E-mail: daniela tonizza@yahoo.com.br.
} 
The question is: how the practical approach to the phenomenon of drug abuse has advanced as from the innovations proposed?

\section{Objectives}

- To Check as the real demands of work experienced by teams of health care for alcohol and drug users in CAPS ad have been addressed by brazilian research communities;

- To discuss the relevance of the conceptual and methodological references of Activity Ergonomics for understanding and transformation of work situations by encouraging the development of competence in such contexts.

\section{Methodology}

Exploratory research through literature review of brazilian publications in the last ten years, including theses, dissertations and articles indexed in the databases SciELO, BIREME, EBSCO, USP, UFBA, UFPR, BVSalud. Descriptors were used: Work, Centers of Psyco-social Attention, alcohol and drugs. The publications consulted were categorized into two thematic groups and analyzed based on the concepts of prescribed work / real work and variability in ergonomics of the activity [2,3].

\section{Results}

The work in CAPS is the subject of numerous studies over the past five years. Testing and studies focused on the meanings and representations of professional work of CAPS $[4,5,6,7,8,9,10]$ converge on some points:

- Conflicts between positive views and the adversities such as precarious work, material failure, severity of cases;

- Points of conflict between professionals;

- Practice oscillating between the reform psychiatric ethics and hospice care strategies;

- Ideals of social inclusion hardly reached that impact in discouragement and psychological distress in the team;

- Reconnaissance of the transformation of care and reaffirmation of the psychiatric reform;
- Affirmation of the need to create spaces to rethink and reformulate the theories and practices continuously.

Studies focused on the content of work in CAPS ad are scarce and recent, but they point to some contradictions. Research involving interviews and participant observation are divided into two main groups:

Souza et al [12], Pinho [13], Shiwokawa [14] and Fodra and Costa Rosa [15] point out that although the health conception proposed is in the psychosocial paradigm, the answer is still focused on the traditional. Attribute that mainly to:

- Disconnect between the service network

- Insufficient engagement of professionals with psychosocial rehabilitation.

- Influence of the physician model on the professional training.

- Discrepancy between the degree of development of technology and degree of development of the workforce.

- Decision-making within the team is already moving in the direction of horizontality, however, is not extended to users, mid-level staff, relatives and the community.

Alves [16] and Silva [17] show results more optimistic, pointing the CAPS ad as a powerful strategy for humanization of care and recovery of citizenship of users and families.

\section{Discussion and final considerations}

The real work is not sufficiently addressed in most studies referenced by prioritizing the analysis of final results, ignoring the content of the work and present variability in work situations. Research on the work that emphasize speech and do not consider the size of the analysis of activity will get "a mutilated approach work situations" [18].

The introduction of new mod-care technologies modify the content of the work and the conditions for the development of skills to achieve desired productivity, affecting the relations of exchange and cooperation between workers and can impact in your health.

Ergonomics can contribute to understanding and transforming the work of such teams by considering the diversity of training, learning and experience in the implementation of supports to promote the continued development of competences (Abraham, 2000). 


\section{References}

[3] Abrahão, J. I. Reestruturação Produtiva e Variabilidade do Trabalho: Uma Abordagem da Ergonomia. Psicologia: Teoria e Pesquisa, v. 16, n. 1, (2000), 49-54.

[15] Alves, V. S. Avaliação da eficiência da rede de atenção à saúde mental e da resolutividade do Centro de Atenção Psicossocial Álcool e Drogas - CAPSad. Tese (Doutorado em Saúde Coletiva), Universidade Federal da Bahia, 2009.

[1] Brasil, Ministério da Saúde. Secretaria Executiva. Secretaria de Atenção à Saúde. Coordenação Nacional DST/Aids. A política do Ministério da Saúde para a atenção integral a usuários de álcool e outras drogas. Brasília: Ministério da Saúde, 2004.

[4] Bueno, M.L; Capoi, S. A construção do discurso dos sujeitos envolvidos com o processo de reforma psiquiátrica: um estudo sobre o município de Joinville/SC. Interface - Comunic., Saúde, Educ, v.13, n.28, (2009), 137-50.

[5] Garcia, M.L; Jorge, M.S. Vivência de trabalhadores de um centro de atenção psicossocial: estudo à luz do pensamento de Martin Heidegger e Hans-Georg Gadamer. Ciência \& Saúde Coletiva, v.11, n.3, (2006), 765-774.

[15] Fodra, R.E.P.; Costa-Rosa, A. Centro de Atenção Psicossocial álcool e drogas (CAPad): análises dos discursos e da prática no contexto da reforma Psiquiátrica e atenção psicossocial. Saúde em Debate, Rio de Janeiro, v. 33, n. 81, (2009), 129139.

[2,18] Guérin, F. et al. Compreender o trabalho para transformá-lo: a prática da ergonomia. São Paulo: Edgard Blucher Ltda, 2001.

[7] Leão, A.; Barros, S. As Representações Sociais dos Profissionais de Saúde Mental acerca do Modelo de Atenção e as Possibilidades de Inclusão Social, Saúde Soc., São Paulo, v.17, n.1, (2008), 95-106.

[8] Lima, M. Entre o discurso e a prática: Há Reforma? Universidade Católica de Pernambuco, Dissertação (Mestrado em Psicologia Clínica), Recife, 2006.

[9] Nardi, H.C.; Ramminger, T. Modos de Subjetivação dos Trabalhadores de Saúde Mental em Tempos de Reforma Psiquiátrica PHYSIS: Rev. Saúde Coletiva, Rio de Janeiro, n. 17, v. 2, (2007), 265-287.

[10] Nunes, M. et al, A dinâmica do cuidado em saúde mental: signos, significados e práticas de profissionais em um Centro de Assistência Psicossocial em Salvador, Bahia, Brasil, Cad. Saúde Pública, Rio de Janeiro, n. 24, v. 1, (2008), 188-196.

[12] Pinho, P. H. Desafios na Atenção ao usuário de álcool e drogas e a Reabilitação Psicossocial. Dissertação (Mestrado em Enfermagem). Universidade de São Paulo, 2009

[13] Shiokawa, E. Avaliação da eficiência da rede de atenção à saúde mental e da resolutividade do Centro de Atenção Psicossocial Álcool e Drogas - CAPS ad. Tese (Doutorado em Farmacologia), Universidade Federal do Paraná, 2010.

[16] Silva, A. M. Tratamento do Centro de atenção Psicossocial para usuários de álcool e outras drogas CAPSad II leste Natal/RN: uma avaliação da efetividade. Dissertação (Mestrado) Centro de Ciências Sociais Aplicadas. Universidade Federal do Rio Grande do Norte. Natal, 2006.

[11] Souza, J. et al.. Centro de Atenção Psicossocial álcool e drogas e redução de danos: novos desafios, Rev. Enferm. UERJ, n.15, v.2, (2007), 210-7.

[6] Vasconcelos, V. C.; Azevedo, C. S. Sentidos do trabalho e imaginário organizacional em um Centro de Atenção Psicossocial - CAPS. Interface - Comunic., Saúde, Educ, v.14, n. 34

(2010), 